\title{
Effect of Mental Imagery Exercises on the Level of Technical Performance of Some Skills on the Floor Exercise Apparatus in Gymnastics
}

\author{
Dr / Shady Mohamad Al henawy \\ Faculty of Physical Education - Mansoura University
}

\section{1/0 Introduction:}

Gymnastics relies on the player's ingenuity in the performance of kinetic chains on various gymnastics devices, where mastery of these skills depends on high-level technical performance, and this is confirmed by Wasim Suleiman (2015) that the gymnast can use the mental perception to assure himself of the temporal elements and the possibility to participate in Technical performance on different gymnastics devices (13:21)

Mahmoud al-Atrash (2009) states that mental imagery of performing a certain skill leads to muscle activity as a result of nerve signals sent from the nervous system to working muscles, where mastery of gymnastics skills depends on repeating correct performance many times to support the nerve pathways responsible for implementing the skill, and through mental imagery pathways can be strengthened. $(17: 15)$

Heba Nadim (2009) notes that training of some mental capabilities such as mental relaxation, mental imagery, the focus of attention, etc. must be carried out along with physical and technical preparation to reach higher levels of sports. $(3: 20)$

Mahmoud Annan (1995) agrees with Ezzat Kashif (1991) and Singer R.N (1980) on the importance of preparing the player in a comprehensive and balanced way physically, technically, mentally and psychologically, as the efficiency of skill performance requires physical, skill and mental imagery. This reflects the need for gymnastics preparation programs to include training directed to develop and develop their mental abilities, in order to bring the player to the athletic form. (112: 16), (24:6), (36:30)

Martens, et al. Martens, R. (1990) indicates that training of some mental skills such as mental imagery, focus of attention and other mental skills should be carried out in parallel with physical training and skill preparation from comprehensive preparation programs. (20:28)

In this regard, Mustafa Abdel Salam (1998) and Deitrich Harra (1982) agree that mental training is one of the pillars of the player's outstanding skill performance as it extends to include the use of all body senses to develop performance. And that high athletic achievements require a great deal of mental abilities, which is what must be emphasized during training before reaching competitions, and mental training skills have become the decisive factor in winning and achieving excellence in championships. $(2: 18),(25: 12)$

1/2 The importance and problem of the research: 
By training the gymnastics team in the Qassim region in the Kingdom of Saudi Arabia, the researcher noticed a deficiency in the level of technical performance For some of the back path skills on the floor exercise apparatus, which may negatively affect the degree of the player in the routine of the floor exercise apparatus, and the researcher assumes that this problem Because of a lack of mental ability to visualize, which may affect the level of technical performance of players in the technical skills understudy.

Therefore, the researcher resorted to designing a set of mental imagery exercises to treat technical deficiencies in order to develop the performance of players, and thus raise the level of players on the floor exercise apparatus, and perhaps it will serve as the legal scientific reference that can be relied upon by workers in the field of sports training and gymnastics.

The importance of the research lies in the researcher's attempt to get acquainted with the mental abilities associated with the technical performance of the skills under consideration, and to improve these abilities in a way that contributes to developing the technical performance of the players, to improve their degrees in competitions.

\section{1/3 Research Goals:}

This study aims to develop the level of technical performance of the skills of the floor exercise apparatus understudy, through:

1/3/1 Developing the dimensions of mental imagery of the individuals in the sample understudy. $1 / 3 / 2$ Designing mental imagery exercises to develop the technical performance level of the skills understudy.

$1 / 3 / 3$ Identifying the percentage of improvement in the level of technical performance of the skills understudy.

\section{1/4 Research Hypothesis:}

1/4/1 There are statistically significant differences between the pre and post measurements of the experimental group in the dimensions of mental imagery understudy in favor of the post measurement.

1/4/2 There are statistically significant differences between the pre and post measurements of the experimental group in the level of technical performance of the gymnastics skills understudy in favor of the post measurement.

\section{1/5 Research Terms:}

1/5/1 Mental Imagery

It is a successful reconfiguration or retrieval of the motor skills or required performance

method and a high degree of clarity and control without actually performing it. (210: 46)

1/5/2 Visual Imagery

It is the invocation of a visual image of kinetic skill in the mind from previous experience, including its degree of clarity and the ability to control its stability. (7:20)

1/5/3 Auditory Imagery

It is the call-up of stimuli for kinetic skill, including volume, duration of sound, pitch and direction of sound. $(18: 15)$

1/5/4 Imagery Emotional 
It is the recall of the formation of the emotional state associated with motor skill, which is evident in apparent behavior and physiological functions. (18:15)

1/5/5 Kinesthesia Imagery

It is the recall of the sensory and perceptual experiences that the player feels during the motor skill in the mind, which includes the nature of movement, the intensity of the kinesthetic sense, the duration of the kinetic sense in the body, the location of the feeling and the emotional aspects accompanying the motor performance. (7:20)

1/5/6 Imagery Control

The player can control and stabilize the kinetic skill created in the mind for a while. (19:15)

1/5/7 Mental Training: Mental Training

It is one of the special training methods that aim to develop some mental capabilities related to gymnastics skills to develop technical performance and prepare for competitions. $(7: 20)$

\section{2/0 Research Procedures:}

2/1 Research Methodology:

The researcher used the experimental method using the experimental design of one group and by making the two measurements (pre-post).

2/2 Spatial Domain: gymnastics hall - halls complex at the Qassim University - Buraidah City Kingdom of Saudi Arabia.

2/3 Time Domain: The exploratory study was conducted in the time period from 20-31 / 5 / 2018 , and the pre-measurement was conducted on Friday 1/6/2018. The basic study was carried out during the period from Sunday, 3/6/2018 to Thursday 23/8/2018, and the post measurement was carried out on Saturday 25/8/ 2018.

\section{2/4 Research Sample:}

The primary study sample was chosen intentionally by gymnasts of the Qassim University team, and the sample included (10) players, as well as (3) players to conduct the exploratory study to codify the training loads for the proposed mental Imagery exercises

\section{$2 / 4 / 1$ Statistical description of sample}

\section{Table (1) \\ Statistical description of growth rates variables \\ (Height - Weight - Age - Training Age)}

\begin{tabular}{c|c|l|c|c|c|c|c|}
\multicolumn{2}{|c|}{$(n=10)$} & $\begin{array}{c}\text { Statistical data } \\
\text { Variables }\end{array}$ & $\begin{array}{c}\text { measuring } \\
\text { unit }\end{array}$ & Mean & $\begin{array}{c}\text { standard } \\
\text { deviation }\end{array}$ & Median & $\begin{array}{c}\text { Coefficient } \\
\text { of torsion }\end{array}$ \\
\hline \hline \multirow{2}{*}{$\begin{array}{c}\text { Growth } \\
\text { rates }\end{array}$} & 1 & Tall & $\mathrm{cm}$ & 170.9 & 2.558 & 170 & 1.055 \\
\cline { 2 - 8 } & 2 & Weight & $\mathrm{Kg}$ & 67.9 & 2.131 & 68 & -0.141 \\
\cline { 2 - 8 } & 3 & Age & Year & 17.71 & 0.218 & 17.65 & 0.824 \\
\hline
\end{tabular}



4 Training age
Year
3.4
0.249
3.5
$-1,203$

From Table (1) it is clear that the values of the torsion coefficient for each of the variables (growth rates) under investigation ranged between $(-1.203,1.055)$ and that these values were limited between $( \pm 3)$ which indicates the moderation of the values of the growth rates of the individuals in the sample under consideration before experimenting.

Table (2)

Statistical description of (dimensions of mental imagery) variables

$(n=10)$

\begin{tabular}{|c|c|c|c|c|c|c|c|}
\hline & & $\begin{array}{l}\text { Statistical data } \\
\text { Variables }\end{array}$ & $\begin{array}{c}\text { measuring } \\
\text { unit }\end{array}$ & Mean & $\begin{array}{l}\text { standard } \\
\text { deviation }\end{array}$ & Median & $\begin{array}{c}\text { Coefficient } \\
\text { of torsion }\end{array}$ \\
\hline \multirow{5}{*}{$\begin{array}{l}\text { Dimensions } \\
\text { of mental } \\
\text { imagery }\end{array}$} & 1 & $\begin{array}{c}\text { visual } \\
\text { imagery }\end{array}$ & degree & 37.7 & 0.823 & 37.5 & 0.728 \\
\hline & 2 & $\begin{array}{l}\text { auditory } \\
\text { imagery }\end{array}$ & degree & 33.6 & 3.373 & 33 & 0.533 \\
\hline & 3 & $\begin{array}{l}\text { kinesthetic } \\
\text { imagery }\end{array}$ & degree & 40.8 & 2.658 & 40 & 0.902 \\
\hline & 4 & $\begin{array}{c}\text { Emotional } \\
\text { imagery }\end{array}$ & degree & 39.4 & 1.349 & 39.5 & -0.222 \\
\hline & 5 & $\begin{array}{l}\text { Control } \\
\text { imagery }\end{array}$ & degree & 41.3 & 2.406 & 42 & -0.827 \\
\hline
\end{tabular}

From Table (2) it is clear that the values of the torsional coefficient for each of the variables (dimensions of mental imagery) understudy ranged between $(-0.827,0.902)$ and that these values were limited between $( \pm 3)$ which indicates the moderation of the values for the mental imagery dimensions of the sample individuals research before experimenting.

Table (3)

Statistical description of (level of technical performance) variables

$(n=10)$

\begin{tabular}{|c|c|c|c|c|c|c|c|}
\hline \hline \multicolumn{2}{|c|}{} & $\begin{array}{c}\text { Statistical data } \\
\text { Variables }\end{array}$ & $\begin{array}{c}\text { measuring } \\
\text { unit }\end{array}$ & Mean & $\begin{array}{c}\text { standard } \\
\text { deviation }\end{array}$ & Median & $\begin{array}{c}\text { Coefficient } \\
\text { of torsion }\end{array}$ \\
\hline \hline \multirow{2}{*}{$\begin{array}{c}\text { level of } \\
\text { technical } \\
\text { performance }\end{array}$} & 1 & $\begin{array}{c}\text { Skill 1 } \\
\text { Round Off }\end{array}$ & degree & 2.5 & 0.336 & 2.55 & -0.446 \\
\cline { 2 - 8 } & 2 & $\begin{array}{c}\text { Skill 2 } \\
\text { Back Hadspring }\end{array}$ & degree & 2.39 & 0.218 & 2.4 & -0.137 \\
\cline { 2 - 8 } & 3 & $\begin{array}{c}\text { Skill 3 } \\
\text { Back Somersault } \\
\text { Tuck }\end{array}$ & degree & 2.39 & 0.191 & 2.35 & 0.627 \\
\cline { 2 - 9 } & 4 & Routine & degree & 8.66 & 0.699 & 8.75 & -0.386 \\
\hline \hline
\end{tabular}


From Table (3) it is clear that the values of the torsion coefficient for each of the variables (the level of technical performance) understudy ranged between $(-0.446,0.627)$ and that these values were limited between $( \pm 3)$ which indicates the moderation of the values of the level of technical performance of the individuals of the sample individuals research before experimenting.

\section{2/5 Means of data collection:}

The researcher used the following methods to collect data:

2/5/1 Means of collecting data on mental imagery.

2/5/2 Anthropometric data collection methods.

2/5/3 The means of collecting technical performance data understudy.

2/5/1 Means of collecting data on the mental imagery of the study:

A mental imagery scale in the sports field is attached (2).

2/5/2 Anthropometric data collection methods:

The means and tools for data collection that are appropriate to the nature of the study were identified by looking at the scientific references, research and previous studies in the field of gymnastics training and some other sports. The researcher has used the following tests, measures and devices:

A rest-meter device for measuring the total length of the body up to the nearest $1 \mathrm{~cm}$.

- The medical scale device to measure the student's weight up to the nearest $1 \mathrm{~kg}$.

2/5/3 Means of collecting data on the technical performance level of the skills under study: The technical skills under study were filmed using the "video camera" and the videos were shown to four arbitrators accredited by the Egyptian Gymnastics Federation to evaluate the technical performance of the skills understudy, where each rule monitored a score of five degrees for each technical skill of the skills and a degree of fifteen degrees for the technical sentence understudy, the highest and lowest grades were omitted, so the player's average is the average of the two intermediate levels.

In this regard, Mohamed Hassanein (2010) and Mohamed Khalil (2018) indicate that the Subjective Evaluation is the type of evaluation that does not depend on the standards, levels, and criteria, but depends on the experiences of the measurers (arbitrators), and the legal evaluation is used in many Of sports activities, especially gymnastics, diving, rhythmic gymnastics and water ballet, where uniform international legal conditions are established, agreed upon in advance between the arbitrators, so that the greatest degree of objectivity can be reached in assessing the degree. (42:13), (9: 9). 


\section{Table (4)}

Technical skills understudy

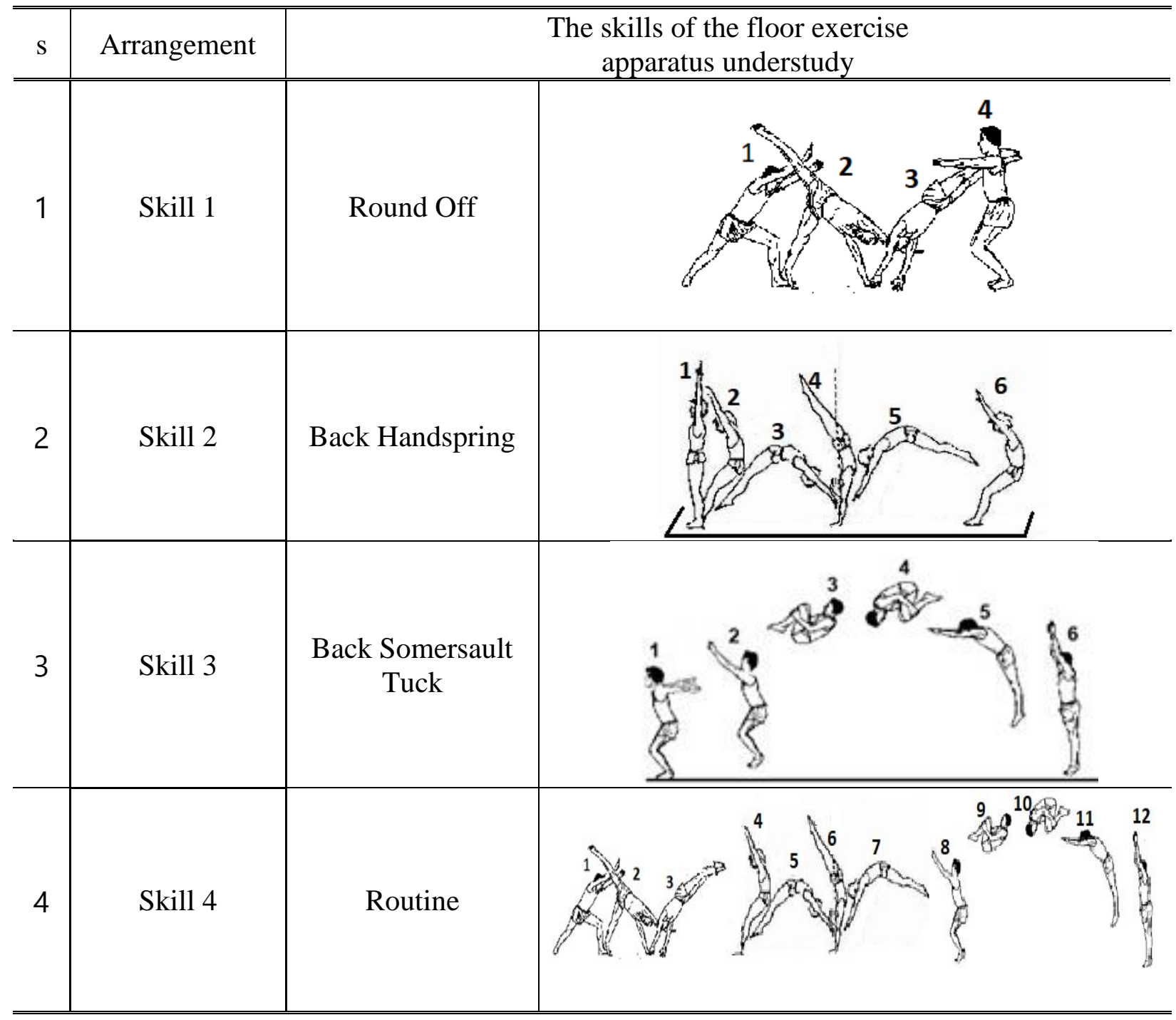

2/6 Selecting the assistants: 
A number of (2) assistants from the Department of Physical Education and Kinesiology were chosen to assist the researcher in applying the study procedures.

\section{2/7 The Exploratory Study:}

The researcher conducted the exploratory study in the time period from 20-31 / 5 / 2018, based on a sample of players represented by the original community and outside the basic research sample. They numbered (3) players who were chosen in a random manner. The pre-measurement was conducted on Friday, 1 / 6 / 2018.

This study has targeted:

- Ensure the safety of the devices and tools used

- Discovering and treating difficulties during measurements.

- Training assistants to take measurements

- Selecting and experimenting with mental perception training appropriate to the aim of the study and its suitability for the age of the research sample

- Control and codification of training load variables for mental imagery exercises understudy.

- Adjusting the best angle of shooting with the camera to facilitate the process of assessing the technical performance of the skills understudy.

The Exploratory Study resulted in:

Ensuring that all of its objectives are achieved, and that the proposed exercises under consideration are appropriate to the nature of the age stage, as the survey sample members conducted the mental imagery exercises without any difficulties, which provided the researcher with the ability to apply these exercises to the members of the basic research sample.

\section{2/8 Basic study:}

The basic study was carried out during the period from Sunday, 3/6/2018, until Thursday, 23/8/2018, and the post-measurement was carried out on Saturday, 25/8/2018, and the pre and post skill performance was photographed at the gymnastics hall in the halls complex Of Sports in the Qassim University. As shown in the attached schedule (5).

\section{2/9 Statistical Treatments:}

The researcher used the program (Statistical Package for Social Sciences) (SPSS v25)

(Statistical Package for Social Science) in statistical processing

Using the following statistical parameters:

- SMA. Standard Deviation - Median

- Torsional coefficient - Wilcoxon test - Percentage of improvement. 
3/0 Presentation and discussion of the results:

3/1 Present the results:

3/1/1 Presenting the results of the first hypothesis:

Table (5)

Significance of the differences between the pre and post measurements for the experimental group in the dimensions of mental imagery variables

$N=10$

\begin{tabular}{|c|c|c|c|c|c|c|c|c|c|}
\hline & \multirow[b]{2}{*}{$\mathrm{s}$} & \multirow[b]{2}{*}{ variables } & \multirow{2}{*}{$\begin{array}{l}\text { Pre } \\
\text { mean }\end{array}$} & \multirow{2}{*}{$\begin{array}{l}\text { Post } \\
\text { mean }\end{array}$} & \multicolumn{2}{|c|}{$\begin{array}{c}\text { Positive } \\
\text { ranks }\end{array}$} & \multicolumn{2}{|c|}{$\begin{array}{l}\text { Negative } \\
\text { ranks }\end{array}$} & \multirow{2}{*}{$\begin{array}{l}(\mathrm{Z}) \\
\text { Value }\end{array}$} \\
\hline & & & & & $\begin{array}{l}\text { mean } \\
\text { rank }\end{array}$ & $\begin{array}{l}\text { Sum } \\
\text { of } \\
\text { ranks }\end{array}$ & $\begin{array}{l}\text { mean } \\
\text { rank }\end{array}$ & $\begin{array}{c}\text { Sum } \\
\text { of } \\
\text { ranks }\end{array}$ & \\
\hline \multirow{5}{*}{$\begin{array}{c}\text { Dimensions } \\
\text { of mental } \\
\text { imagery }\end{array}$} & 1 & $\begin{array}{c}\text { visual } \\
\text { imagery }\end{array}$ & 37.7 & 59.4 & 5.5 & 55.0 & 0.00 & 0.00 & $-2.810^{*}$ \\
\hline & 2 & $\begin{array}{l}\text { Auditory } \\
\text { imagery }\end{array}$ & 33.6 & 49.2 & 5.5 & 55.0 & 0.00 & 0.00 & $-2.812^{*}$ \\
\hline & 3 & $\begin{array}{c}\text { kinesthetic } \\
\text { imagery }\end{array}$ & 40.8 & 60.5 & 5.5 & 55.0 & 0.00 & 0.00 & $-2.807^{*}$ \\
\hline & 4 & $\begin{array}{c}\text { Emotional } \\
\text { imagery }\end{array}$ & 39.4 & 61.2 & 5.5 & 55.0 & 0.00 & 0.00 & $-2.807^{*}$ \\
\hline & 5 & $\begin{array}{c}\text { Control of } \\
\text { mental imagery }\end{array}$ & 41.3 & 63.4 & 5.5 & 55.0 & 0.00 & 0.00 & $-2.823^{*}$ \\
\hline
\end{tabular}

* Tabular value $(\mathrm{Z})$ at the level of $0.05= \pm 1.96$

From Table (5) it is clear that the calculated value of $(Z)$ for each of the variables (dimensions of mental imagery) understudy has ranged between $(-2.807,-2.823)$ and that these values are not limited to \pm 1.96 which indicates the presence of statistically significant differences. between the mean of the pre-post measurements of the experimental group in favor of the post measurement at the level of significance $(0.05)$ in the variables of mental imagery dimensions.

Figure (1)

Significance of the differences between the pre and post measurements for the experimental group in the dimensions of mental imagery variables 


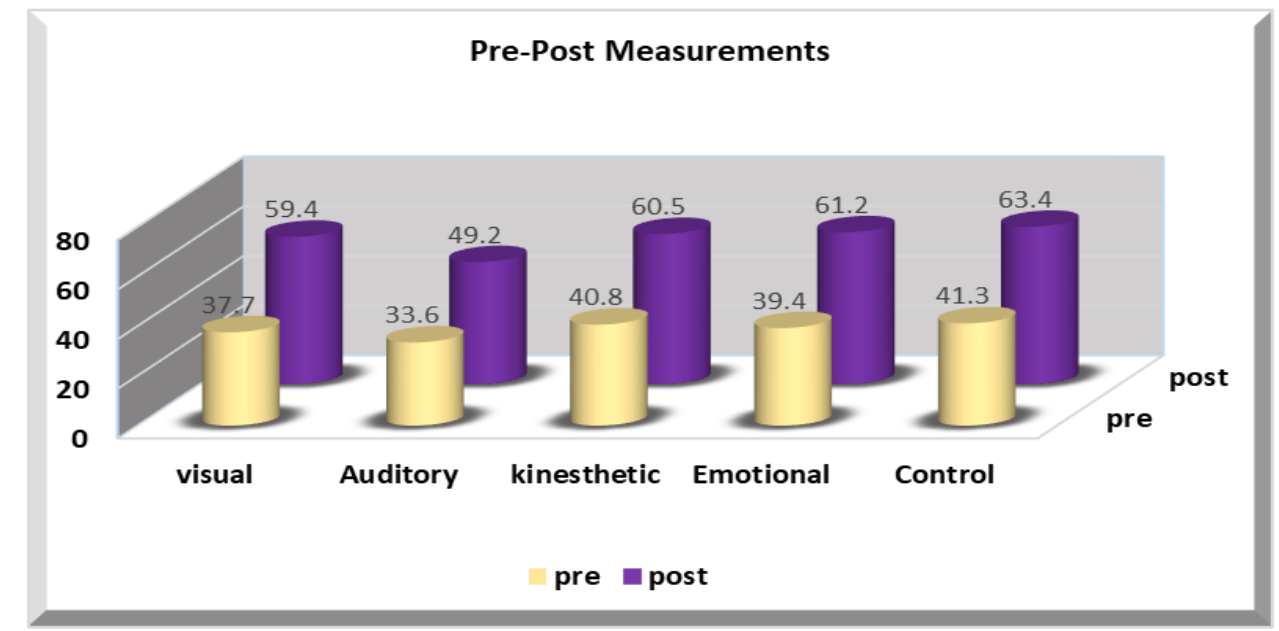

Table (6):

The percentage improvement of the experimental group In the dimensions of mental imagery

\begin{tabular}{|c|c|c|c|c|c|c|}
\hline & $\mathrm{S}$ & variables & $\begin{array}{l}\text { Pre } \\
\text { mean }\end{array}$ & $\begin{array}{l}\text { Post } \\
\text { mean }\end{array}$ & $\begin{array}{c}\text { Difference } \\
\text { between } \\
\text { the two } \\
\text { Means }\end{array}$ & $\begin{array}{l}\text { Percentage } \\
\text { of } \\
\text { improvemen }\end{array}$ \\
\hline \multirow{5}{*}{$\begin{array}{l}\text { Dimensions } \\
\text { of mental } \\
\text { imagery }\end{array}$} & 1 & $\begin{array}{c}\text { visual } \\
\text { imagery }\end{array}$ & 37.7 & 59.4 & 21.7 & $57.6 \%$ \\
\hline & 2 & $\begin{array}{l}\text { auditory } \\
\text { imagery }\end{array}$ & 33.6 & 49.2 & 15.6 & $46.4 \%$ \\
\hline & 3 & $\begin{array}{c}\text { kinesthetic } \\
\text { imagery }\end{array}$ & 40.8 & 60.5 & 19.7 & $48.3 \%$ \\
\hline & 4 & $\begin{array}{c}\text { Emotional } \\
\text { imagery }\end{array}$ & 39.4 & 61.2 & 21.8 & $55.3 \%$ \\
\hline & 5 & $\begin{array}{c}\text { Control of } \\
\text { mental } \\
\text { imagery }\end{array}$ & 41.3 & 63.4 & 22.1 & $53.5 \%$ \\
\hline
\end{tabular}

From Table (6) it is clear that the percentage of improvement of the experimental group in the dimensions of mental imagery ranged between $(46.4 \%, 57.6 \%)$ and that the highest percentage of improvement was visual imagery of (57.6\%) and the lowest percentage of improvement was for auditory imagery by $(46.4 \%)$ and the rest of the dimensions ranged between them.

Figure (2)

The percentage improvement in variables Dimensions of mental imagery 


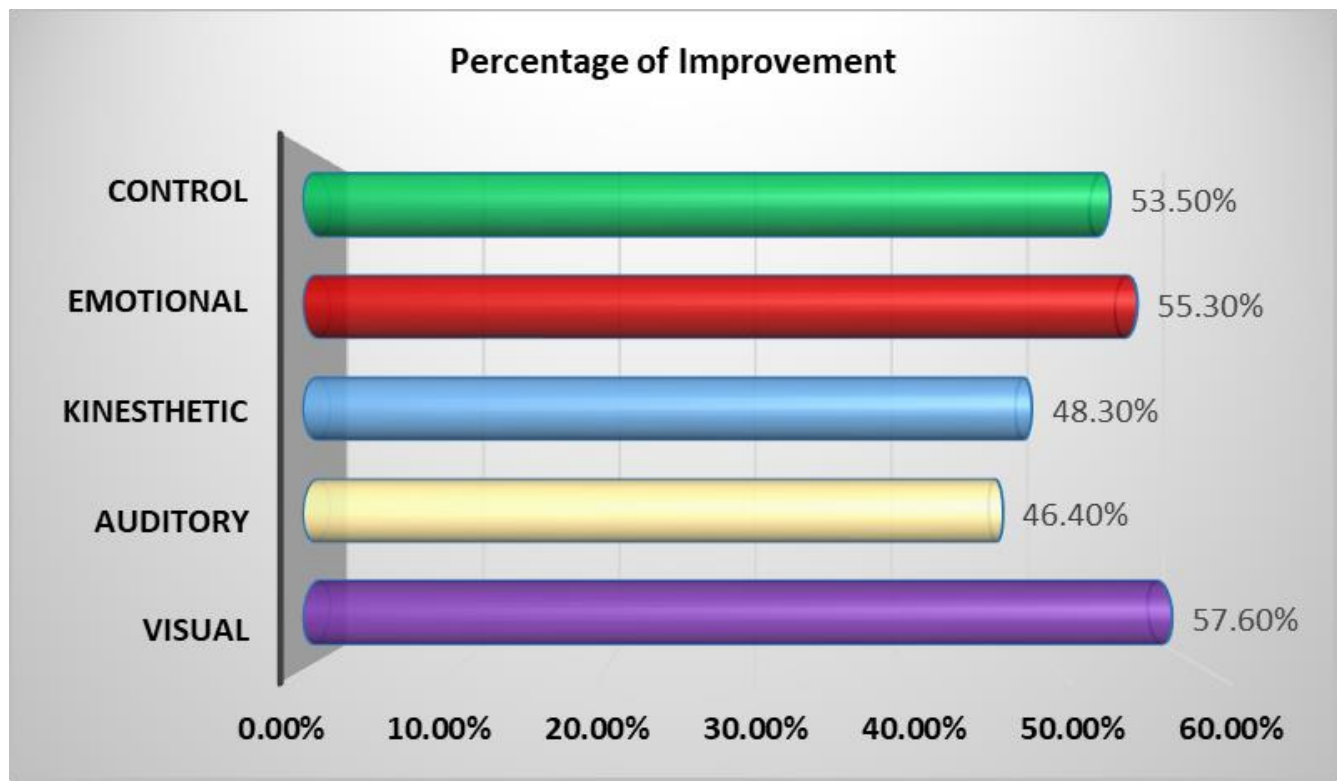

3/2/2 Presenting the results of the second hypothesis:

Table (7)

Significance of the differences between the pre and post measurements for the experimental group in technical performance variables

$n=10$

\begin{tabular}{|c|c|c|c|c|c|c|c|c|c|}
\hline & \multirow[b]{2}{*}{$\mathrm{s}$} & \multirow[b]{2}{*}{ variables } & \multirow[b]{2}{*}{$\begin{array}{l}\text { Pre } \\
\text { mean }\end{array}$} & \multirow[b]{2}{*}{$\begin{array}{l}\text { Post } \\
\text { mean }\end{array}$} & \multicolumn{2}{|c|}{$\begin{array}{c}\text { Positive } \\
\text { ranks }\end{array}$} & \multicolumn{2}{|c|}{$\begin{array}{l}\text { Negative } \\
\text { ranks }\end{array}$} & \multirow[b]{2}{*}{$\begin{array}{l}\text { (Z) } \\
\text { Value }\end{array}$} \\
\hline & & & & & $\begin{array}{l}\text { mean } \\
\text { rank }\end{array}$ & $\begin{array}{c}\text { Sum } \\
\text { of } \\
\text { ranks }\end{array}$ & $\begin{array}{l}\text { mean } \\
\text { rank }\end{array}$ & $\begin{array}{c}\text { Sum } \\
\text { of } \\
\text { ranks }\end{array}$ & \\
\hline \multirow{4}{*}{$\begin{array}{c}\text { level of } \\
\text { technical } \\
\text { performance }\end{array}$} & 1 & $\begin{array}{c}\text { Skill } 1 \\
\text { Round Off }\end{array}$ & 2.50 & 3.43 & 5.5 & 55.0 & 0.00 & 0.00 & -2.810 \\
\hline & 2 & $\begin{array}{c}\text { Skill } 2 \\
\text { Back Handspring } \\
\end{array}$ & 2.39 & 3.65 & 5.5 & 55.0 & 0.00 & 0.00 & -2.810 \\
\hline & 3 & $\begin{array}{c}\text { Skill } 3 \\
\text { Back Somersault } \\
\text { Tuck } \\
\end{array}$ & 2.39 & 3.50 & 5.5 & 55.0 & 0.00 & 0.00 & -2.825 \\
\hline & 4 & Routine & 8.66 & 12.54 & 5.5 & 55.0 & 0.00 & 0.00 & -2.810 \\
\hline
\end{tabular}

* Tabular value $(\mathrm{Z})$ at the level of $0.05= \pm 1.96$

From Table No. (7) it is clear that the calculated value of $(\mathrm{Z})$ for each of the (technical performance) variables understudy ranged between $(-2.810,-2.825)$ and that these values are not limited to \pm 1.96 , which indicates that there are statistically significant differences between the mean of the pre-post measurements of the experimental group in favor of the post measurement at the level of significance (0.05) in the variables of the level of technical performance.

\section{Figure (3)}

Significance of the differences between the pre and post measurements for the experimental group in technical performance variables 


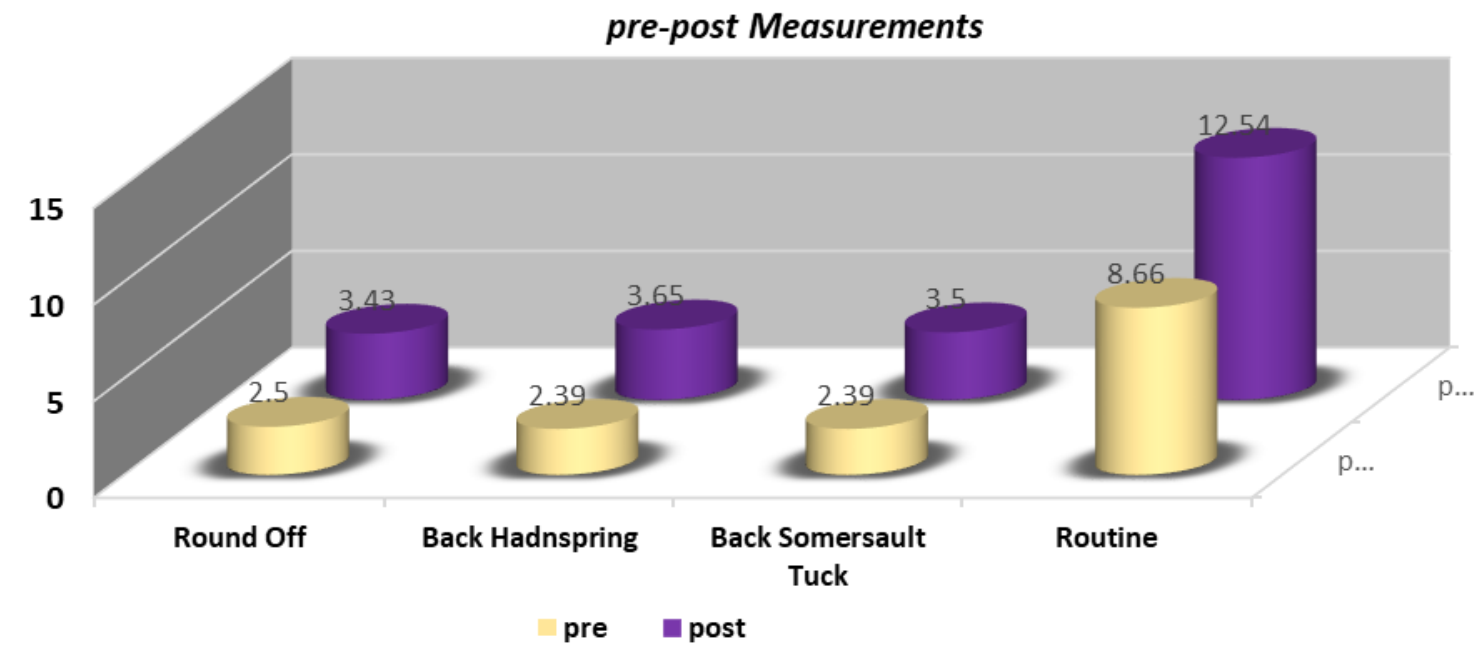

Table (8)

The percentage improvement of the experimental group in technical performance variables

\begin{tabular}{|c|c|c|c|c|c|c|}
\hline & $\mathrm{s}$ & $\begin{array}{c}\text { Pre } \\
\text { mean }\end{array}$ & $\begin{array}{c}\text { Post } \\
\text { mean }\end{array}$ & $\begin{array}{c}\text { Difference } \\
\text { between } \\
\text { the two } \\
\text { Means }\end{array}$ & $\begin{array}{c}\text { Percentage } \\
\text { of } \\
\text { improvement }\end{array}$ \\
\hline \hline \multirow{2}{*}{$\begin{array}{c}\text { level of } \\
\text { technical } \\
\text { performance }\end{array}$} & 1 & $\begin{array}{c}\text { Skill 1 } \\
\text { Round Off }\end{array}$ & 2.50 & 3.43 & 0.930 & $37.2 \%$ \\
\cline { 2 - 7 } & 3 & $\begin{array}{c}\text { Skill 2 } \\
\text { Back Handspring }\end{array}$ & 2.39 & 3.65 & 1.260 & $52.7 \%$ \\
\cline { 2 - 7 } & 4 & $\begin{array}{c}\text { Skill 3 } \\
\text { Back Somersault } \\
\text { Tuck }\end{array}$ & 2.39 & 3.50 & 1.110 & $46.4 \%$ \\
\hline \hline
\end{tabular}

From Table (8) it is clear that the percentage of improvement of the experimental group in the variables of technical performance ranged between $(37.2 \%, 52.7 \%)$ and that the highest percentage improvement was the second skill by $(52.7 \%)$ and the lowest percentage improvement was the first skill by $(37.2 \%)$ and the rest of the variables ranged between them .

\section{Figure (4)}

The percentage improvement of technical performance variables 


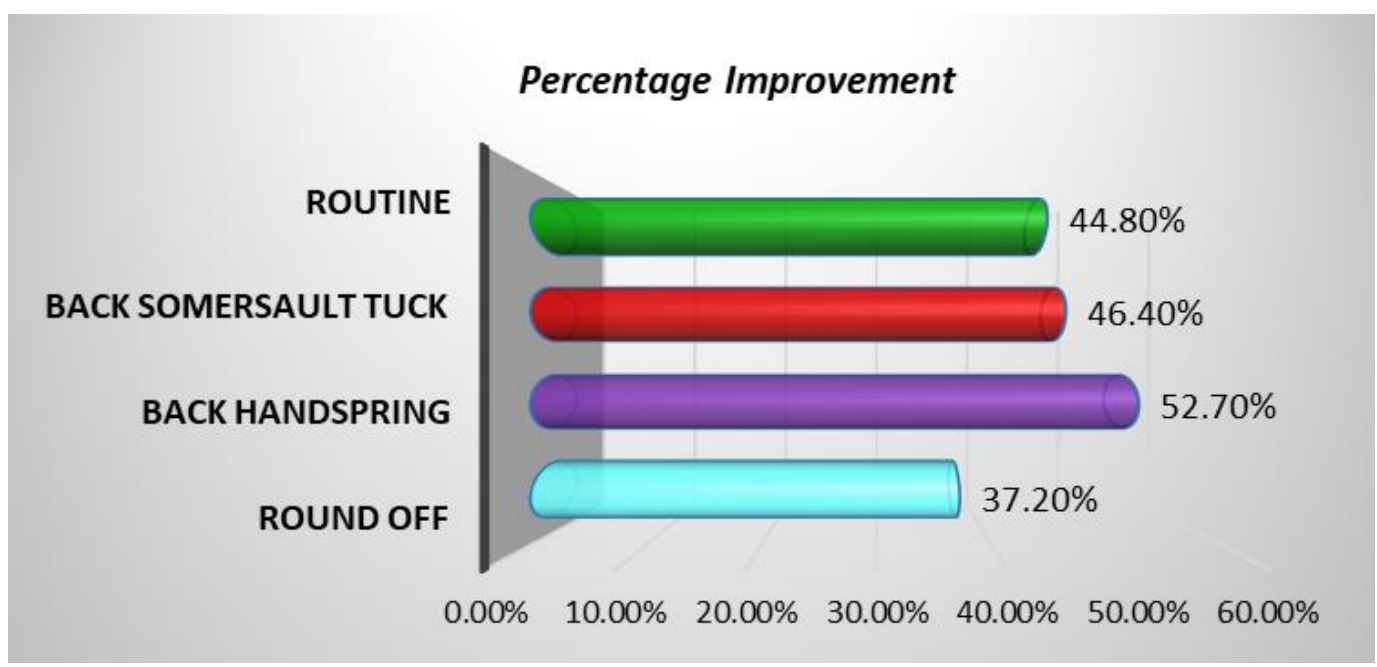

\section{2/2 Discuss the results:}

\section{3/2/1 Discussing the results of the first hypothesis:}

Which states, "There are statistically significant differences between the pre and post measurements of the experimental group in the dimensions of mental imagery understudy in favor of the post measurement."

It is clear from Table No. (5) and Figure No. (1) that there are statistically significant differences at the level of $(0.05)$ between the pre and post measurements of the experimental group in favor of the post-measurement in the parameters of mental imagery dimensions where the value of the $(\mathrm{Z})$ tabular at the level of $0.05=( \pm 1.96)$, While the calculated value of $(\mathrm{Z})$ for each of the variables (mental imagery dimensions) understudy ranged between $(-2.807,-2.823)$ and that these values are all less than (-1.96), meaning that they are not limited to \pm 1.96 , which indicates that there are differences Statistical significance between the averages of the pre and post measurements of the experimental group in favor of the post measurement, at the level of significance $(0.05)$ in the parameters of mental imagery dimensions. The researcher attributes these results to the effect of mental imagery exercises understudy, and regular training per week at a rate of (3) training units per week.

It is also clear from Table No. (6) and Figure No. (2) that there are statistically significant differences between the pre and post measurements of the experimental group in favor of the postmeasurement in the parameters of mental imagery dimensions, with an improvement rate ranging between $(46.4 \%, 57.6 \%)$, where the average degree of The level of visual imagery the pre measurement was (37.7 degrees), and it became in the post measurement (59.4 degrees), with an improvement rate which is the highest by (57.6\%). With an improvement rate (55.3\%), and in the second place was the average degree of emotional imagery in pre measurement (39.4 degrees) and became in post-measurement (61.2 degrees). With an improvement rate $(53.5 \%)$, and in the third 
place was the average degree of control of mental imagery in pre measurement (41.3 degrees) and became in post-measurement (63.4 degrees). With an improvement rate (48.3\%), and in the fourth place was the average degree of kinesthetic imagery in pre-measurement (40.8 degrees) and became in post-measurement (60.5 degrees). With an improvement (46.4\%), and in fifth place was the average degree of auditory imagery in pre- measurement (33.6 degrees) and became in postmeasurement (49.2 degrees).

It is also noted that the averages of the post-measurements are higher than the premeasurements in all variables of the dimensions of mental imagery understudy, where visual imagery achieved the highest improvement rate among the five dimensions of mental imagery, with an improvement rate of $(57.6 \%)$, followed by the emotional imagery with an improvement rate of $(55.3 \%)$, and is attributed The researcher has these differences to mental imagery exercises, whereby the proposed training units included targeted training for each type of different mental imagery (visual imagery, auditory imagery, kinesthetic imagery, emotional imagery, control of imagery), and even progress in the ability to mental imagery Consideration has been given to trying to develop these dimensions in a comprehensive and balanced way, and that mental imagery contains everything related to the technical skills to be visualized, but without the actual performance of it.

These results are consistent with what the results of the studies of Mahmoud Al-Atrash (2009) (15) and Suhair Al-Lakany (2004) (5) and Majdi Mahmoud (2000) (8) "Feeny.TB" (1997) (26) show that mental imagery has a positive and effective impact in developing the level of motor skills performance. This mental imagery training with its various dimensions is an important basis in mental training programs as it contributes to developing good skill and increases the body's driving forces and raises morale and works to develop and deepen the sense of success. This is confirmed by the study of Medhat Ibrahim (2004) (17) that the mental imagery dimensions related to the nature of performance are the most affected by the proposed exercises.

In this regard, Muhammad Allawi (2008) points out that mental imagery requires the use of all senses to retrieve perceptions, images and ideas previously understood by the individual, or requires the production of new images and ideas in the mind of the individual. (11:249)

Based on the foregoing results, the first hypothesis that states: (There are statistically significant differences between the pre and post measurements of the experimental group in the

variables of the dimensions of mental imagery understudy in favor of the post measurement) have been achieved.

\section{3/2/2 Discussing the results of the second hypothesis:}

Which states, "There are statistically significant differences between the pre and post measurements of the experimental group in the level of technical performance of gymnastics skills understudy in favor of the post measurement."

It is clear from Table No. (7) and Figure No. (3) that there are statistically significant differences at the level of (0.05) between the pre and post measurements of the experimental group 
in favor of the post measurement in the level of technical performance of the gymnastics skills understudy, where the value of the $(Z)$ table at the level of $0.05=( \pm 1.96)$, while the calculated value of $(Z)$ for each of the (technical performance) variables understudy ranged between $(-2.810$, $-2.825)$ and that these values are all less than $(-1.96)$ meaning that they are not limited to \pm 1.96 which indicates There are statistically significant differences between the averages of the pre and post measurements of the experimental group in favor of the post measurement at the significance level (0.05) in the technical performance variables of the gymnastics skills understudy. The researcher attributes these results to the effect of mental imagery exercises understudy, and regular training per week at a rate of (3) training units per week.

It is also clear from Table No. (8) and Figure No. (4) that there are statistically significant differences between the pre and post measurements of the experimental group in favor of the post measurement in the variables of the technical performance level, with an improvement rate ranging between $(37.2 \%, 52.7 \%)$, where the average skill level The second in the pre-measurement was (2.39 degrees) and it became in the post-measurement (3.65 degrees) with an improvement rate which is the highest by $(52.7 \%)$, and in the second place was the average degree of the third skill in the pre-measurement (2.39 degrees) and became in the post-measurement (3.50 degrees) With an improvement rate $(46.4 \%)$, and in the third place was the average degree of the technical sentence in the tribal measurement (8.66 degrees) and became in the dimensional measurement (12.54 degrees) with an improvement rate $(44.8 \%)$, and in the fourth place was the average degree of first skill in the tribal measurement (2.50 Degrees) and became in post-measurement (3.43 degrees), with an improvement $(37.2 \%)$.

It is also noted that the averages of the post measurements are higher than the pre in all the variables of technical performance understudy, as the second skill achieved the highest improvement rate among the variables of technical performance, with an improvement rate of (52.7\%), followed by the third skill with an improvement rate of $(46.4 \%)$, and the researcher attends this The improvement to the mental visualization exercises under consideration, where the researcher applied exercises to develop mental imagery by using the sensory dimensions (visual, auditory, kinesthetic) and emotional imagery through visualizing the degree of emotion that is appropriate to the nature of skill performance and stressful situations in the championship. The exercises also included exercises Image clarity and image control, which helped the player visualize the complex performance of the technical sentence in all its detail, with full control over the ability to retrieve the performance method while seeing it clearly and doing its analysis.

These results are consistent with the results of the studies of "Heba Nadim" (2008) (20), "Sameh Al-Shabrawi" (2007) (4), and Rasha Al-Baghdadi (2005) (3) and "Medhat Ibrahim" (2005) (17), "Suhair Talaat" (2004) (5), "Muhammad Anbar" (2000) (14), "Basmat Ali" (1998) (2), "Walid Sayed" (2000) (22), "Najla Mahdi" (1997) (19) and" Ahmed Khalil "(1997) (1), where they unanimously agreed on the importance of integration between mental training and skill training to upgrade the technical level of motor skills and the level of achievement in general.

In this regard, Jake Pearson (2001) (27) and Dariusz Nowicki (1997) (24) agree that the implementation of mental imagery exercises correctly through mental imagery of skill performance helps to learn skills in a correct technical manner more quickly, and thus Technical performance development. 
Muhammad Al-Arabi (2001), Butt (1987), Nideffer (1985), Jack \& Judy (1982) and Issam Helmy (1980) confirm the importance of mental training as an essential part of a player's overall preparation before entering into competitions, and that developing mental capabilities is an important means For all levels of sports and for all ages for developing artistic performance with the aim of winning the championship, as mental training helps isolate performance disruptions, and increases focus on achievement. (31: 10-32), (18:23), (29:35), (27:113), (118: 7)

Based on the foregoing results, it is clear that mental imagery exercises have a positive effect on the level of technical performance of the gymnastics skills understudy, as this has been shown through improvement rates.

Thus, the second hypothesis has been fulfilled, which states: "There are statistically significant differences between the pre and post measurements of the experimental group in the level of technical performance of the gymnastics skills understudy in favor of the post measurement."

\section{4/0 Conclusions and Recommendations:} 4/1 Conclusions:

Based on what the research results showed, and in light of the research goal and hypotheses, the researcher reached the following conclusions:

4/1/1 The proposed mental imagery exercises have an effective effect on the dimensions of mental imagery understudy, through:

4/1/1/1 The average degree of visual imagery in the pre-measurement was ( 37.7 degrees), and it became in the post-measurement (59.4 degrees), with an improvement rate that is the highest by (57.6\%)

4/1/1/2 The average degree of emotional imagery in pre-measurement was (39.4 degrees), and it became in post-measurement (61.2 degrees), with an improvement rate (55.3\%).

$4 / 1 / 1 / 3$ The average degree of control of mental imagery in pre- measurement was (41.3 degrees) and became in post-measurement (63.4 degrees), with an improvement rate $(53.5 \%)$

4/1/1/4 The average degree of kinesthetic imagery in the pre-measurement was (40.8 degrees) and it became in the post-measurement (60.5 degrees) with an improvement rate (48.3\%)

$4 / 1 / 1 / 5$ The average degree of auditory imagery in pre- measurement was (33.6 degrees), and it became in post-measurement (49.2 degrees), with an improvement rate (46.4\%).

4/1/2 The proposed mental imagery exercises having an effective effect on the variables of the technical performance level of the gymnastics skills understudy, through:

4/1/2/1 The average skill for the (Round Off) in the pre-measurement was (2.50 degrees) and it became in the post-measurement (3.43 degrees) with an improvement rate (37.2\%)

4/1/2/2 The average degree of (Back Handspring) in the pre-measurement was (2.39 degrees) and it became in the post-measurement (3.65 degrees) with an improvement rate which is the highest by (52.7\%) 
4/1/2/3 The average score for the (Back Somersault Tuck) in the pre-measurement was (2.39 degrees) and it became in the post-measurement (3.50 degrees) with an improvement rate (46.4\%) 4/1/2/4 The average degree of the (Routine) in the pre- measurement was (8.66 degrees) and it became in the post-measurement (12.54 degrees), with an improvement rate (44.8\%).

\section{4/2 Recommendations:}

Based on the results of the research results and the conclusions reached, the researcher recommends the following:

4/2/1 Application of mental imagery exercises to develop and develop the level of technical performance in gymnastics.

4/2/2 The merger between training (mental abilities, fitness, technical level) with the goal of comprehensive preparation for the player, to reach the highest level of achievement.

4/2/3 Educating the trainers about the importance and how to apply mental imagery exercises, in line with the technical performance requirements for each of the gymnastics skills.

4/2/4 Application of mental imagery exercises in the skill preparation phase and the prechampionship period at the beginning, middle and end of the training unit after warming up, to make the most of mental work.

4/2/5 The application of mental imagery exercises to the various gymnastics apparatus, and to other dental stages.

4/2/6 Conducting more studies on mental abilities by using advanced measurement methods such as the EEG

\section{5/0 References:}

\section{5/1 Arabic References:}

1- Ahmed Salah El-Din Khalil (2002), The electrical activity of the brain as a function of the effectiveness of thinking strategies to develop the level of performance and reduce stress among athletes. Unpublished doctoral dissertation, Faculty of Physical Education for Boys in Cairo, Helwan University.

2- Basmat Muhammad Ali (1998), The effect of a mental training program on the level of offensive and defensive performance of karate players. Master Thesis, Faculty of Physical Education, Minia University.

3- Rasha Al-Baghdadi (2005), The effect of a mental visualization program on the level of kata performance. Unpublished Master Thesis, Faculty of Physical Education - Tanta University.

4- Sameh Al-Shabrawi Tantawi (2007), The effect of a proposed mental training program on the level of kata performance and some mental aspects of juniors in karate from 14-16 years. Research published in the Scientific Journal of Physical Education and Sports Sciences, 8th issue, March.

5- Suhair Talaat Al-Lakani (2004), A proposed training program using mental training to improve the level of transmission performance, transmission response, and developing some mental skills in tennis. The Scientific Journal of Physical Education and Sports, No. 27, July, Faculty of Physical Education for Girls, Alexandria University. 
6- Izzat Mahmoud Al-Kashef (1991), Psychological preparation for athletes. Dar Al-Fikr Al-Arabi, Cairo.

7- Issam Mohamed Helmy (1980), Swimming training between theory and practice. Dar AlMaarif, Alexandria.

8- Majdi Mahmoud Fahim (2000), The effect of developing mental perception on the state of competition anxiety and their relationship to the level of performance of competitors. PhD thesis, unpublished, Faculty of Physical Education for Boys, Zagazig University.

9- Mohamed El-Sayed Khalil (2018), Tests and measurements in physical education. Unpublished notes, Faculty of Physical Education, Mansoura University.

10- Muhammad Al-Arabi Shamoun (2001), Mental training in the sports field. Second edition, Dar Al-Fikr Al-Arabi, Cairo.

11- Mohamed Hassan Allawi (2006), Psychology of training and competitions. Ninth Edition, Dar Al-Maarif, Cairo.

12- Muhammad Hassan Allawi (2008), Psychology Training and Sports Competition. Arab Thought Center, Cairo.

13- Mohamed Sobhy Hassanein (2010), Measurement and Evaluation in Physical Education and Sports. Part one, fifth edition, Dar Al-Fikr Al-Arabi, Cairo.

14- Muhammad Anbar Muhammad (2000), The electrical activity of the brain as an indicator to develop the level of triple jump performance using mental training. PhD thesis, Faculty of Physical Education, Cairo, Helwan University.

15- Mahmoud Al-Atrash (2009), The effect of a proposed training program for psychological skills on developing the level of skill and planning performance of football players. Published research, An-Najah University Journal for Humanities Research, Volume 22 (5), College of Physical Education, An-Najah National University, Nablus, Palestine.

16- Mahmoud Abdel Fattah Annan (1995), The Psychology of Physical Education and Sports. Theory, application and experimentation, Dar Al-Fikr Al-Arabi, Cairo.

17- Medhat Mahmoud Ibrahim (2004), Mental training using time perception and effective performance in karate. Unpublished Master Thesis, Faculty of Physical Education for Boys in Al Haram - Helwan University.

18- Mustafa Abdel Salam Mustafa (1998), The effect of a mental training program to develop some mental skills on the accuracy of the performance of the free throw for young men and women in basketball. Unpublished Master Thesis, Faculty of Physical Education for Boys in Al Haram, Helwan University.

19- Naglaa Fathi Mahdi (1997), The effect of a proposed mental training program on developing motor rhythm and the level of performance in technical exercises. Unpublished Master Thesis, Faculty of Physical Education - Helwan University.

20- Heba Mahmoud Nadim (2008), The effect of mental training on reducing competition anxiety and the effectiveness of the skilled performance of taekwondo players. 
Unpublished doctoral dissertation, Faculty of Physical Education for Girls, Alexandria University.

21- Waseem Oqab Suleiman (2015), The effect of a mental perception program on the level of skill performance and psychological compatibility of young football players. Unpublished Master Thesis, College of Physical Education, An-Najah National University, Nablus, Palestine.

22- Walid Muhammad Syed (1998), The effect of using mental training on the performance of kata for karate players. Faculty of Physical Education, Master Thesis, Menoufia University.

\section{5/2 Foreign References:}

23- Butt, D.S (1987). Psychology of sport, the behavior motivation personality and performance of Athletes ;2end; ed Van no.8, Trand Reinhold co. New York.

24- Dariusz Nowicki (1997). Mental Training - The Key to peak Performance in Martial Arts Sport, 1997 http://www.stadion.com

25- Deitrich Harra (1982). Principles of sport training , sportvelag Berlin.

26- Feeny,T.B (1997). Perception of high school student athletes of coaching competence, microform publications int. for sport and human performance, university of organ.

27- Jack, H. L., Judy, A.B. (1982). Psychology of coaching Theory and Application, Burgess, Pub. co. U.S.A.

28- Martens, R., Vealey,R.S., Burton,D (1990). Competitive anxiety in sport, human kinetic Pub. Inc. Champaign, Illinois, U.S.A.

29- Nideffer. RM (1985). Athletes Guide to mental Training, human kinetic Pub. Inc. Champaign, Illinois, U.S.A.

30- Singer R.N. (1980). Motor Learning and Human Performance, $3^{\text {rd }}$ ed, MC million Pub. $\mathrm{Co}, \mathrm{Nc}$. 